\title{
A Case of Acute Lymphoblastic Leukaemia Presenting with Wrist Pain at the Emergency Department
}

\author{
Bilek Ağrısı ile Acil Servise Başvuran Akut Lemfoblastik Lösemi Olgusu
}

Asım Kalkan', Selman Yeniocak², Özlem Bilir' , Gökhan Ersunan

'Department of Emergency Medicine, Faculty of Medicine, Recep Tayyip Erdoğan University, Rize, Turkey 2Department of Emergency Medicine, Haseki Education and Research Hospital, İstanbul, Turkey

\section{ABSTRACT}

Introduction: Leukaemias are a group of heterogenous neoplastic diseases resulting from malignant transformation of hematopoietic cells. Acute leukaemias are the group of diseases characterised by the infiltration of immature myeloid or lymphoid series cells into the blood, bone marrow or other tissues. In acute leukaemias, joint pain is one of the rare causes of presentation at the emergency services. In this report, we addressed the importance of haemogram evaluation by the emergency department physicians for patients with joint pain.

Case Report: An 18-year old male presented at the emergency department with complaints of pain in the left wrist which had been ongoing for one week. The patient had no history of trauma and direct graphics was normal. Blood test results were determined as leukocytes $41900 / \mathrm{mm}^{3}$.

Conclusion: It is important to look at haemogram results of patients presenting at the emergency department with complaints of simple joint pain. As the basis for evaluation of leukaemia and similar haematological diseases, a haemogram is a simple test which can be applied in every emergency department.

Keywords: Acute lymphoblastic leukaemia, wrist pain, haemogram Received: 15.09.2012 Accepted: 20.03.2013

\section{ÖZET}

Giriş: Lösemiler hemopoetik hücrelerin malign transformasyonu sonucu oluşan heterojen neoplastik hastalıklar grubudur. Akut lösemiler immatur myeloid veya lenfoid seri hücrelerinin kan, kemik iliği veya diğer dokuları infiltrasyonu ile karakterize hastalık grubudur. Akut lösemilerde eklem ağrısı acil servise nadir başvuru sebeplerinden biridir. Bu yazıda acil servise eklem ağrısı ile başvuran hastalarda hemogram bakmanın önemini vurguladık.

Olgu Sunumu: On sekiz yaşında erkek hasta bir haftadır devam eden sol el bileğinde ağrı şikayetiyle acilimize müracaat etti. Travma öyküsü yoktu ve lökosit değeri 41900/mm³ idi.

Sonuç: Basit eklem ağrısı şikâyeti ile acil servise başvuran hastalarda hemogram bakmak önemlidir. Lösemi ve diğer hematolojik hastalıkların değerlendirilme temeli olan basit hemogram çalışması her acil serviste yapılmalıdır.

Anahtar Kelimeler: Akut lemfositik lösemi, eklem ağrısı, hemogram Geliş Tarihi: 15.09.2012 Kabul Tarihi: 20.03.2013

\section{Introduction}

Leukaemias are a group of heterogenous neoplastic diseases resulting from malignant transformation of hematopoietic cells. Acute leukaemias are the group of diseases characterised by the infiltration of immature myeloid or lymphoid series cells into the blood, bone marrow or other tissues. Acute lymphoblastic leukaemia (ALL), is a heterogenous disease with different subtypes showing typical clinical, biological and prognostic characteristics. Two thirds of all ALL cases are seen in children. ALL is the most frequently encountered neoplastic disease in children below the age of 15 years. The incidence of ALL in adults varies between 1-2/100,000 (1). Bone pain has been reported in 21-59\% of patients and radiological impairments in 7.7- 70\%. Joint 
pain is one of the causes of frequent presentation at the emergency services (2). Although most often associated with trauma, there may be a connection with a more serious cause such as acute lymphocytic leukaemia. The case is presented here of rarely seen chloroma in a patient presenting at the emergency department with complaints of wrist pain, and emphasis is placed in this report on the importance of haemogram evaluation by the emergency department physicians for patients with joint pain.

\section{Case Report}

An 18-year old male presented at the emergency department with complaints of pain in the left wrist which had been ongoing for one week. The physical examination determined his general condition to be good, fully conscious, blood pressure $110 / 70 \mathrm{mmHg}$, pulse $80 /$ min, respiratory rate $16 / \mathrm{min}$, body temperature $36.4^{\circ} \mathrm{C}$, tenderness in the left wrist and bilateral cervical lymphadenopathy. There was no hepatosplenomegaly or abdominal mass.

The patient had no history of trauma and there were no characteristics of note on the wrist and pulmonary radiographs. Blood test results were determined as urea: $50 \mathrm{mg} / \mathrm{dl}$, uric acid: $10.9 \mathrm{mg} / \mathrm{dl}$, lactate dehydrogenase (LDH): $644 \mathrm{mg} / \mathrm{dl}$, CRP: $2.98 \mathrm{mg} / \mathrm{dl}$, leukocytes 41900/mm3 (7.2\% neutrophil, 16.7\% lymphocyte, 14.6\% monocyte, 0.0\% eosinophil and 61.5\% basophil) Hb: 9.7g/dl, Plt: 104000/uL. Peripheral blood smear results were determined as $2 \%$ partial neutrophils, 3\% lymphocyte, 7\% blast, $88 \%$ erythrocyte morphology target cell (+), reduced thrombocytes formed in clusters of 4, narrow/moderate width blasts, cytoplasmic non-granulous, nucleus with regular/jagged contours and nucleolus (+/-). ALL was considered so the patient was admitted to the haemotology department for further tests and treatment.

\section{Discussion}

The most important clinical signs and symptoms of acute leukaemia occur with the infiltration of leukaemic cells into the bone marrow or other organs and the impairment of normal hematopoesis and functions of affected organs (3). The period between the onset of symptoms and diagnosis varies from a few days to a few weeks. Bone marrow activity and the infiltration of increasing leukaemic cells into the bone tissue results in bone and joint pain, synovitis and joint swelling. It is often confused with acute joint rheumatism or juvenile rheumatoid arthritis. Even when there is no pain, radiological signs can be observed such as periosteal reaction, osteosclerosis, osteoporosis and osteolysis, mostly in the metaphyseal band $(2,4)$. In addition, palpation of the sternum may be painful. Occasionally bone lesions imitate osteomyelitis and there may be confusion in the diagnosis (5). In the case presented here, the patient had no other complaints than the joint pain for a week. No pathology was observed in the wrist and pulmonary radiographs which were taken. Bilateral cervical lymphadenomegaly was determined in the physical examination.

The main clinical signs of acute leukaemias are fatigue associated with anaemia, tiringquickly, palpitations and dypsnea on exertion, haemorrhage due to thrombocytopenia and a tendency to infec- tions due to neutropenia. All types of bacterial, viral, fungal and protozoal infections may be seen associated with granulocytopenia. Although fever is generally a sign of infection, it may be related to the general systemic effect of the disease. On physical examination, the skin and mucous are pale. Haemorrhage may be in the form of petechiae on the skin, ecchymosis and purpurae. There is often bleeding from the nose, gums and conjunctiva. When the thrombocyte count falls below 20000/ $\mathrm{mm}^{3}$ there is increased risk of haemorrhage (6). If there is leukostasis, haemorrhage may occur in the lungs or the musculoskeletal system (MSS). Leukostasis occurs more often when the blast number is $>100000 / \mathrm{mm}^{3}$. Blasts accumulate in the small veins of organs such as the brain, retina, lungs, penis and gastrointestinal organs and lead to infarct and haemorrhage. Loss of appetite and weight loss are frequently encountered complaints (7). Lymphadenomegaly, liver dysfunction and hepatomegaly due to leukaemic cells infiltrating the liver, and a mediastinal mass associated with lymph nodes or thymus growth may be determined by pleural effusion. MSS involvement is seen in less than 55\% of cases during diagnosis. In patients with increased intracranial pressure, vomiting, headaches and papilloedema occur, and focal neurological findings due to invasion of the parenchyma, hemiparesis and convulsions may also develop. Ataxia, dysmetria and hypotonia may be seen associated with cerebellar involvement (8). In the examination of the case presented here, there were no skin findings, infarct, haemorrhage, organomegaly, anaemia-related symptoms, weight loss, fever or neurological findings.

Characteristic blood laboratory test results of acute leukaemias are advanced stage anaemia, thrombocytopenia and the presence of blasts on smear preparations (9). However, at the time of first diagnosis, normal blood laboratory values may be determined in 10\% of patients. In general, there are normochromic normocytes. Anisocytosis, poikilocytosis and polychromasia can be seen. The thrombocyte count is generally low from the onset and half of cases are below 50000/ $\mathrm{mm}^{3}$. Large, poorly granulated thrombocytes showing impaired function can be seen. The main laboratory finding of acute leukaemias is the presence of blastic cells. In the laboratory blood test results of the case presented here, leukocytosis with basophil dominance, anaemia, mild thrombocytopenia, and non-granulated thrombocytes were observed and blast dominance in the peripheral smear (6).

Hyperuricemia can be seen resulting from increased purine metabolism in leukaemic cells. Leukaemic cell destruction often leads to increased levels of serum LDH (10). In our case the uric acid and LDH levels were high.

\section{Conclusion}

It is important to examine haemogram results of patients presenting at the emergency department with complaints of simple joint pain. As the basis for evaluation of leukaemia and similar haematological diseases, a haemogram is a simple test which can be applied in every emergency department. It can be concluded that emergency department physicians should give importance to blood count test results in the evaluation of patients presenting with joint pain. 
Conflict of Interest: No conflict of interest was declared by the authors.

Peer-review: Externally peer-reviewed.

Informed Consent: Written informed consent was obtained from patients who participated in this case.

Author Contributions: Concept - A.K.; Design - A.K.; Supervision S.Y., O.B.; Funding - G.E.; Materials - A.K., S.Y.; Data Collection and/ or Processing - A.K., S.Y.; Analysis and/or Interpretation - G.E., O.B.; Literature Review - O.B., S.Y.; Writer - A.K.; Critical Review - A.K., S.Y.

Financial Disclosure: The authors declared that this study has received no financial support.

Çıkar Çatışması: Yazarlar çıkar çatışması bildirmemişlerdir.

Hakem değerlendirmesi: Dış bağımsız.

Hasta Onamı: Yazılı hasta onamı bu olguya katılan hastalardan alınmıştır.

Yazar Katkıları: Fikir - A.K.; Tasarım - A.K.; Denetleme - S.Y., O.B.; Kaynaklar - G.E.; Malzemeler - A.K., S.Y.; Veri toplanması ve/veya işlemesi - A.K., S.Y.; Analiz ve/veya yorum - G.E., O.B.; Literatür taraması - O.B., S.Y.; Yazıyı yazan - A.K.; Eleştirel İnceleme - A.K., S.Y.
Finansal Destek: Yazarlar bu çalışma için finansal destek almadıklarını beyan etmişlerdir.

\section{References}

1. Türk Hematoloji Derneği. Akut lösemiler tanı ve tedavi kılavuzu. 2011; 29.

2. Apak A, Celkan T, Yıldız l, Zeybek C. Akut lenfoblastik lösemide iyi prognoz göstergesi; kemik tutulumu. Cocuk Sagligi Hast Derg 2003; 46: 275-80.

3. Henderson ES. Acute Leukemia: General Considerations. In Williams WJ, Beutler E, Erslev AJ, Hichtman MA, Editors. Hemayology. 4th ed. McGraw Hill Puplishing Company; 1991.p.236-251.

4. Müller HL, Horwitz AE, Kühl J. Acute lymphoblastic leukemia with severe skeletal involvement: a subset of childhood leukemia with a good prognosis. Pediatr Hematol Oncol 1998; 15: 121-33. [CrossRef]

5. Winterstein AR, Bohndorf K, Vollert K, Wagner T, Gnekow A, Roemer FW. Invasive aspergillosis osteomyelitis in children-a case report and review of the literature. Skeletal Radiol 2010; 39: 827-31. [CrossRef]

6. B Tharmalingam H, Naresh K, Bain BJ, Pavlů J. Hypoplastic presentation of acute lymphoblastic leukemia. Am J Hematol 2012; 87: 702. [CrossRef]

7. Daams M, Schuitema I, van Dijk BW, van Dulmen-den Broeder E, Veerman $A J$, van den Bos C, et al. Long-term effects of cranial irradiation and intrathecal chemotherapy in treatment of childhood leukemia: A MEG study of power spectrum and correlated cognitive dysfunction. BMC Neurol 2012; 12: 84. [CrossRef]

8. Carroll WL, Bhojwani D, Min DJ, Raetz E, Relling M, Davies S, et al. Pediatric acute lymphoblastic leukemia. Hematology Am Soc Hematol Educ Program 2003: 102-31. [CrossRef]

9. Champlin R, Golde DW. The leukemias. In Harrison's Principals of Internal Medicine II. Philedelphia: Saunders; 1991.p.1552-61.

10. Rao D, Ghalaut VS, Ghalaut PS, Rao S. Case series: CSF LDH, proteins and electrolyte levels in patients of acute lymphocytic leukemia. Clin Chim Acta 2012; 413: 1045-8. [CrossRef] 